\title{
Correction: The transcription factor NRF2 enhances melanoma malignancy by blocking differentiation and inducing COX2 expression
}

\author{
Christina Jessen - Julia K. C. Kreß (1) - Apoorva Baluapuri $(1)$ - Anita Hufnagel - Werner Schmitz $(D)$ Susanne Kneitz • \\ Sabine Roth - André Marquardt - Silke Appenzeller - Carsten P. Ade (i) - Valerie Glutsch • Marion Wobser • \\ José Pedro Friedmann-Angeli (i) - Laura Mosteo - Colin R. Goding (i) - Bastian Schilling (iD) Eva Geissinger • \\ Elmar Wolf $(\mathbb{D} \cdot$ Svenja Meierjohann $(\mathbb{0})$
}

Published online: 1 December 2020

(c) The Author(s) 2020. This article is published with open access

\section{Correction to: Oncogene \\ https://doi.org/10.1038/s41388-020-01477-8}

Since the publication of this paper there has been an addition to the Acknowledgements section: "Open Access funding enabled and organized by Projekt DEAL". The HTML and PDF versions of the paper have been updated accordingly.

Open Access This article is licensed under a Creative Commons Attribution 4.0 International License, which permits use, sharing, adaptation, distribution and reproduction in any medium or format, as long as you give appropriate credit to the original author(s) and the source, provide a link to the Creative Commons license, and indicate if changes were made. The images or other third party material in this article are included in the article's Creative Commons license, unless indicated otherwise in a credit line to the material. If material is not included in the article's Creative Commons license and your intended use is not permitted by statutory regulation or exceeds the permitted use, you will need to obtain permission directly from the copyright holder. To view a copy of this license, visit http://creativecommons. org/licenses/by/4.0/. 